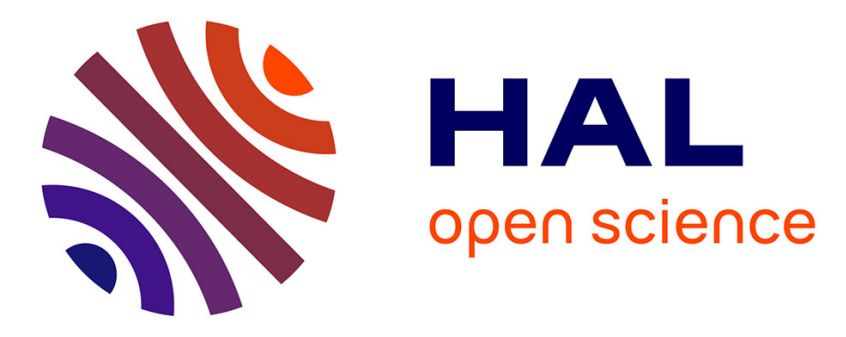

\title{
Growth of diamond films on laser-treated substrates
}

\author{
V. Ralchenko, K. Korotoushenko, A. Smolin, V. Konov
}

\section{To cite this version:}

V. Ralchenko, K. Korotoushenko, A. Smolin, V. Konov. Growth of diamond films on laser-treated substrates. Journal de Physique IV Proceedings, 1994, 04 (C4), pp.C4-187-C4-187. 10.1051/jp4:1994442 . jpa-00252705

\section{HAL Id: jpa-00252705 https://hal.science/jpa-00252705}

Submitted on 1 Jan 1994

HAL is a multi-disciplinary open access archive for the deposit and dissemination of scientific research documents, whether they are published or not. The documents may come from teaching and research institutions in France or abroad, or from public or private research centers.
L'archive ouverte pluridisciplinaire HAL, est destinée au dépôt et à la diffusion de documents scientifiques de niveau recherche, publiés ou non, émanant des établissements d'enseignement et de recherche français ou étrangers, des laboratoires publics ou privés. 


\title{
Growth of diamond films on laser-treated substrates
}

\author{
V.G. RALCHENKO, K.G. KOROTOUSHENKO, A.A. SMOLIN and V.I. KONOV \\ General Physics Institute, Russian Academy of Sciences, ul. Vavilova 38, 117942 Moscow, Russia
}

Polycrystalline diamond films (DF) grown from hydrocarbons at low pressures is highly attractive material for optical, mechanical, electronic and other applications, in which the unique physical and chemical properties of diamond are used. Fabrication of diamond-based electronic devices requires a high resolution patterning of DF, however a conventional post-growth processing (polishing, etching ...) is difficult because of extreme hardness and chemical inertness of diamond. We report on alternative method to produce fine structures in DF - selected-area diamond deposition on laser-irradiated substrates.

CVD diamond films have polycrystalline structure because the film growth is initiated independently on selected nucleation sites randomly distributed over substrate surface. The diamond nucleation sites were artificially created on polished $\mathrm{Si}$ wafer by seeding the ultrafine $(5 \mathrm{~nm})$ diamond powder using ultrasonic pretreatment of the substrate. Then those seeds were removed at selected areas under action of a finely focussed beam of $\mathrm{Ar}+$ laser (488 $\mathrm{nm}$ wavelength) scanned over surface under computer control. At the final step the DF was deposited in DC arc discharge plasma in methane (5\%)/hydrogen (95\%) gas mixtures [1]. Only at unexposed areas the DF did grow, while the growth was totally suppressed at the laser-modified surface. Micron-sized DF patterns have been fabricated by this way. The mechanisms of nucleation centres annihilation, and the role of ambient atmosphere (air, argon) in this effect are discussed.

It is shown also that a laser pre-treatment of $\mathrm{Si}$ may result in a significant reducing in DF surface roughness, $R_{a}$. Smooth DF with $R_{a}<30 \mathrm{~nm}$ were grown, that could be used for optical coating, antifriction coatings and insulating layers in electronic devices.

[1] N.I. Chapliev, V.I. Konov, S.M. Pimenov, A.M. Prokhorov, and A.A. Smolin, in Y. Tzeng, M. Yoshikawa, M. Murakawa and A. Feldman (eds.), Applications of Diamond Films and Related Materials, Elsevier Science Publishers, Amsterdam, 1991, p. 417-421. 